\title{
Contribution of very short-lived organic substances to stratospheric chlorine and bromine in the tropics - a case study
}

\author{
J. C. Laube ${ }^{1,2}$, A. Engel ${ }^{1}$, H. Bönisch ${ }^{1}$, T. Möbius ${ }^{1}$, D. R. Worton ${ }^{2, *}$, W. T. Sturges ${ }^{2}$, K. Grunow ${ }^{3}$, and U. Schmidt ${ }^{1}$ \\ ${ }^{1}$ Institute for Atmosphere and Environment, University of Frankfurt, Germany \\ ${ }^{2}$ School of Environmental Sciences, University of East Anglia, UK \\ ${ }^{3}$ Institute for Meteorology, Free University of Berlin, Germany \\ * now at: Department of Environmental Science, Policy and Management, University of California, Berkeley, USA
}

Received: 17 March 2008 - Published in Atmos. Chem. Phys. Discuss.: 7 May 2008

Revised: 15 September 2008 - Accepted: 30 October 2008 - Published: 11 December 2008

\begin{abstract}
The total stratospheric organic chlorine and bromine burden was derived from balloon-borne measurements in the tropics (Teresina, Brazil, $5^{\circ} 04^{\prime} \mathrm{S}, 42^{\circ} 52^{\prime} \mathrm{W}$ ) in 2005. Whole air samples were collected cryogenically at altitudes between 15 and $34 \mathrm{~km}$. For the first time, we report measurements of a set of 28 chlorinated and brominated substances in the tropical upper troposphere and stratosphere including ten substances with an atmospheric lifetime of less than half a year. The substances were quantified using pre-concentration techniques followed by Gas Chromatography with Mass Spectrometric detection. In the tropical tropopause layer at altitudes between 15 and $17 \mathrm{~km}$ we found $1.1-1.4 \%$ of the chlorine and $6-8 \%$ of the bromine to be present in the form of very short-lived organic compounds. By combining the data with tropospheric reference data and age of air observations the abundances of inorganic chlorine and bromine $\left(\mathrm{Cl}_{\mathrm{y}}\right.$ and $\left.\mathrm{Br}_{\mathrm{y}}\right)$ were derived. At an altitude of $34 \mathrm{~km}$ we calculated $3062 \mathrm{ppt}$ of $\mathrm{Cl}_{\mathrm{y}}$ and $17.5 \mathrm{ppt}$ of $\mathrm{Br}_{\mathrm{y}}$ from the decomposition of both long- and short-lived organic source gases. Furthermore we present indications for the presence of additional organic brominated substances in the tropical upper troposphere and stratosphere.
\end{abstract}

\section{Introduction}

The potential of chlorinated and brominated organic substances to enhance the catalytic destruction of ozone in the stratosphere is well known. Once in the stratosphere, the substances are destroyed by photolysis and reactions with active oxygen $\left(\mathrm{O}^{1} \mathrm{D}\right)$ and $\mathrm{OH}$ radicals. Inorganic bromine is mainly

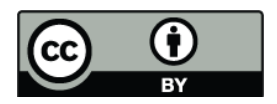

Correspondence to: J. C. Laube (j.laube@uea.ac.uk) present in the form of $\mathrm{BrO}, \mathrm{Br}, \mathrm{HOBr}, \mathrm{BrONO}_{2}$ and $\mathrm{HBr}$. These species and the corresponding chlorine species (including $\mathrm{BrCl}$ and $\mathrm{Cl}_{2} \mathrm{O}_{2}$ ) are responsible for the catalytic destruction of ozone (e.g. Solomon, 1999). Although the abundance of the summed-up chlorine and bromine from longerlived organic gases in the stratosphere has decreased since the late 1990s (e.g. Engel et al., 2002; Montzka and Fraser, 2003) the impact of very short-lived substances (VSLS) on that total remains unsure. Bromine has, on average and on a per atom basis, a 60 times higher efficiency to destroy ozone than chlorine (WMO, 2007). Thus, even very low mixing ratios of brominated substances of less than 0.1 part per trillion (ppt) are of importance for stratospheric ozone depletion. Especially the brominated VSLS are suspected "to make a significant contribution to total stratospheric bromine and its effect on stratospheric ozone" (Law and Sturges, 2007).

The uncertainty in the amounts of VSLS reaching the stratosphere is due to the short atmospheric lifetimes of these substances (less than half a year) compared to atmospheric transport times which leads to a highly variable tropospheric distribution in time and space (Law and Sturges, 2007). Additionally there are very few measurements in the main stratospheric entrance region, the tropical tropopause layer (TTL) or above in the tropical lower stratosphere. Published observations of organic VSLS in the inner tropics above $15 \mathrm{~km}$ are presented in Schauffler et al. $(1998,1999)$, Sinnhuber and Folkins (2006) and Law and Sturges (2007). Schauffler et al. performed measurements of nine brominated substances up to about $21 \mathrm{~km}$ while Sinnhuber and Folkins only used bromoform data from three campaigns in 1996, 1999 and 2004 for comparison with models. Law and Sturges (2007) used available data at altitudes between 10 and $17.5 \mathrm{~km}$ from six measurement campaigns that were carried out within a period of eight years (1996-2004) to

Published by Copernicus Publications on behalf of the European Geosciences Union. 
assess the amount of chlorine and bromine from VSLS that is present in the tropical upper troposphere. Also several model studies were performed to quantify in particular the influence of brominated VSLS to ozone depletion (Dvortsov et al., 1999; Nielsen et al., 2001; Levine et al., 2007). Current estimates of the World Meteorological Organisation for the upper tropical troposphere range from 52 to $60 \mathrm{ppt}$ for chlorine and 3.1 to $4.0 \mathrm{ppt}$ for bromine from VSLS, but measurements show a much higher variability and uncertainty (see e.g. the data set presented in Law and Sturges, 2007).

\section{Analytical procedures}

\subsection{Sampling techniques}

We present results from the flight BII 42 of the whole-airsampler BONBON launched from Teresina, Brazil $\left(5^{\circ} 04^{\prime} \mathrm{S}\right.$, $42^{\circ} 52^{\prime} \mathrm{W}$ ) inside the inter tropical convergence zone on 8 June 2005 with a balloon operated by the French space agency CNES (Centre National d'Etudes Spatiales). This flight was part of a campaign for the validation of the ENVISAT satellite. Between 15.2 and $34 \mathrm{~km}$ altitude 15 samples were collected by pumping air cryogenically into electropolished stainless steel containers (for details see Schmidt et al., 1987; Engel et al., 1997). Three samples could not be analysed due to technical failure during sampling and one sample showed contamination from the balloon exhaust. No samples are available below $15 \mathrm{~km}$ for technical reasons.

\subsection{Measurement techniques}

The whole air samples were analysed in December 2005 using Gas Chromatography with Electron Impact Mass Spectrometric detection (GC-EI-MS; Siemens Sil GC with Agilent 5975 MS) at the University of Frankfurt and in February 2006 with GC-Negative Ion Chemical Ionisation-MS (GCNICI-MS; Agilent 6890/5973, see also Worton et al. (2008) for further analytical details) at the University of East Anglia (UEA). Trace gases in the air samples were enriched cryogenically by cooling the sample loop with liquid nitrogen and using about $300 \mathrm{ml}$ of air (UEA: 2 litres pre-concentrated on two bed adsorbent trap containing Carbograph-TD and Carboxen- 1000 at $-10^{\circ} \mathrm{C}$ using a Peltier cooler). Separation took place on a micro-packed PorasilC/n-octane column (UEA: Restek 502.2 capillary column). The MS was operated in EI-SIM (Selected Ion Monitoring) mode measuring three ions at a time (UEA: NICI-SIM monitoring ions with $\mathrm{m} / \mathrm{z} 35,37,79$ and 81 throughout the chromatogram). The Frankfurt analytical system provides high precisions and detection limits in the lower and sub-ppt range. In EI mode the substances are broken into characteristic cations using a high energy electron beam. This often allows quantification even if several substances elute at the same time. The UEA system uses NICI - a very sensitive and substance-specific method to detect amounts of a few parts per quadrillion (ppq) of especially brominated organic substances (Buser, 1986; Worton et al., 2008). Bromine anions are formed via dissociative electron capture from thermal electrons provided by an ionised reactant gas (here: methane). The masses 79 and 81 in a ratio of 1:1 are typical for bromine in the atmosphere, consisting of a nearly 50:50 mixture of these two isotopes. Chlorine can also be detected in a similar way by measuring on the relevant chlorine masses. However, if substances co-elute no quantification is possible with this method. The NICI detection also allows no certain identification of the detected compounds in the chromatogram and is based on the compounds retention times which must be known.

\subsection{Air mass origin}

Quasi-isentropic trajectories were calculated by the Free University Berlin (FUB) using a model (Langematz et al., 1987; Reimer and Kaupp, 1997) with a resolution of $1.25^{\circ} \times 1.25^{\circ}$ and 59 potential temperature levels and operational ECMWF fields as meteorological input. Above $380 \mathrm{~K}$ heating rates were calculated using the radiative transfer scheme of the SLIMCAT 3-D chemical transport model (Chipperfield, 1999). SLIMCAT heating rates are not available below $380 \mathrm{~K}$. Therefore, diabatic motions below $380 \mathrm{~K}$ were derived based on climatological heating rates and a Newtonian cooling approach. This yields to an ascent of the air masses from $+0.3 \mathrm{~K} /$ day around $356 \mathrm{~K}$ of up to $0.8 \mathrm{~K} /$ day around $400 \mathrm{~K}$. In Fig. 1 ten-day backward trajectories are shown. They were initialised at $5.28^{\circ} \mathrm{S}$ and $44.99^{\circ} \mathrm{W}$ which is the mean geographical location of the samples taken at 15.2 and $16.4 \mathrm{~km}$ altitude. The trajectories show, that the air around $15 \mathrm{~km}$ was most probably coming from North-West while the air around $16.5 \mathrm{~km}$ travelled over South-West South America. Other backward trajectories were initialised $2.5^{\circ}$ north, east, south and west from this place and showed similar results. We conclude that the air sampled in the TTL has most probably been influenced from air masses originating from both hemispheres.

\section{Quality assurance}

\subsection{Concentration drift and blank correction}

It is a known problem that many organic trace gases drift in concentrations if stored in metal containers for longer time periods. These changes depend e.g. on the nature, past use, and pre-treatment of the container surface, the compound, the container pressure, the storage temperature, the ozone content and the water vapour content (Finlayson-Pitts and Pitts, 2000). They can be caused by adsorption or chemical reactions e.g. on active spots of the container walls (Pate et al., 1992; Apel et al., 1994). Surface passivations via fluorination or electro-polishing are common techniques to avoid wall reactions (e.g. Blake et al., 1994) but this is not sufficient 


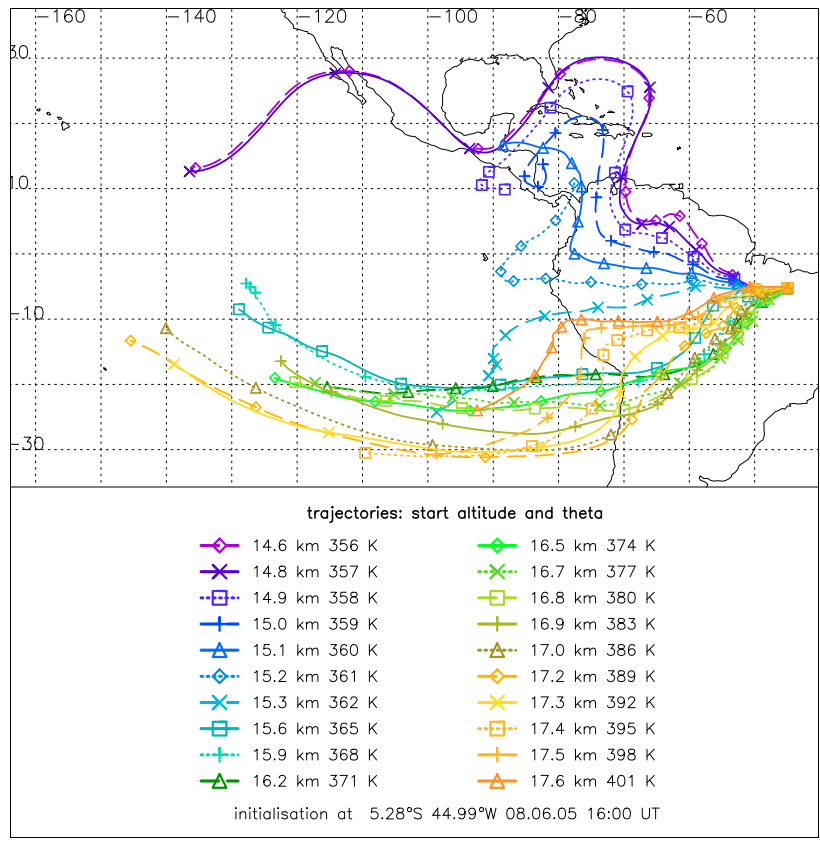

Fig. 1. Quasi-isentropic ten-day backward trajectories calculated with a resolution of $1.25^{\circ} \times 1.254^{\circ}$ on 59 potential temperature levels. They were initialised at $5.28^{\circ} \mathrm{S}$ and $44.99^{\circ} \mathrm{W}$ within the TTL on 8 June 2005. The trajectories show, that the sampled air was coming from both hemispheres.

in all cases. Positive changes with time have also been observed in containers. They can originate from uptake into a film of water on the container surface which can be reversed if pressure is reduced as samples are removed from the container (Finlayson-Pitts and Pitts, 2000).

To assure the quality of the data, three of the sample containers were measured again in August 2007 at the University of Frankfurt. A list of the quantified compounds, their source of calibration and detection limits can be found in Table 1 . The chlorofluorocarbons (CFCs), hydro-chlorofluorocarbons (HCFCs) and halons proved to be stable, whereas the $\mathrm{CH}_{3} \mathrm{Cl}$, $\mathrm{CH}_{2} \mathrm{Cl}-\mathrm{CH}_{2} \mathrm{Cl}$ and $\mathrm{CCl}_{4}$ mixing ratios had drifted systematically in the containers. If changes occurred in all containers that contained the substance they were assumed to be systematic if the mean percentage change exceeded the percentage $1 \sigma$ standard deviation of the samples concentration changes. This means that the variability of the concentration changes did not exceed the changes itself. A wall reaction follows the first-order rate law and can be approximated as a linear process with respect to time if it is slow. Assuming that such a process is responsible for the observed drift we calculated an increase of $0.73 \%(22.4 \mathrm{ppt})$ per month for $\mathrm{CH}_{3} \mathrm{Cl}$, of $2.90 \%$ (0.01 ppt) for $\mathrm{CH}_{2} \mathrm{ClCH}_{2} \mathrm{Cl}$ and a decrease of $1.57 \%$ (4.06 ppt) per month for $\mathrm{CCl}_{4}$ relative to their initially measured values. The mixing ratios of these substances in the air samples were corrected by linear extrapolation of the calculated trends to the flight date. Five other substances
- $\mathrm{CH}_{2} \mathrm{Cl}_{2}, \mathrm{CHCl}_{3}, \mathrm{CH}_{3} \mathrm{CCl}_{3}, \mathrm{C}_{2} \mathrm{Cl}_{4}$ and $\mathrm{CH}_{3} \mathrm{Br}$ - showed changes but these were non-systematic and/or did not occur in all reanalysed samples. For these substances the maximum extrapolated difference (at most $\pm 0.6 \%$ per month) was added to the error bars as a systematic error (see below). The substances measured at the UEA could not be rechecked except for the $\mathrm{CH}_{2} \mathrm{Br}_{2}$ content of one sample which was the same within the measurement uncertainties. Moreover, low mixing ratios of up to $2.7 \mathrm{ppt}$ of $\mathrm{CH}_{2} \mathrm{Cl}_{2}$ were detected in some samples collected above $19 \mathrm{~km}$. As $\mathrm{CH}_{2} \mathrm{Cl}_{2}$ should be completely depleted at these altitudes we suggest nonsystematic processes in the containers (such as out gassing from container valves or production reactions) as an explanation and included these blank values in our error calculation. For the other VSLS we found rather uniform container and system blanks, which were below $0.02 \mathrm{ppt}$ for all species and corrected for them.

\subsection{Intercomparison with ground-based observations}

Most of the longer-lived compounds are measured regularly at remote sampling locations by the Global Monitoring Division (GMD) which belongs to the Earth System Research Laboratory (ESRL) of the National Oceanic Atmospheric Administration (NOAA), USA. Longer-lived trace gases show rather uniform concentrations in the global background and upper troposphere because their atmospheric lifetimes are high compared with the corresponding transport times. In order to check the quality of our measurements we compared the mixing ratios in the sample collected at $15.2 \mathrm{~km}$ with the globally averaged mixing ratios derived from NOAA-ESRL ground-based observations in June 2005. These mixing ratios are publicly available and can be accessed as anonymous ftp data under http://www.esrl.noaa.gov/gmd/. The measurements of F12, F11, F113, F22, F142b, F141b, $\mathrm{CCl}_{4}$, $\mathrm{CH}_{3} \mathrm{CCl}_{3}$ and $\mathrm{H} 1211$ agreed within $3 \%$. In combination with the observed low VSLS mixing ratios (see below) this indicates that a well mixed air mass with little influence from local deep convection was sampled (VSLS would be superelevated in the case of convective influence). Moreover it provides evidence, that the samples were not contaminated e.g. by balloon exhaust. However, three of the longer-lived substances showed higher differences. The first is H1301 which we found to be $8.8 \%$ higher than the NOAA-ESRL reference but still within the $2 \sigma$ measurement uncertainties. The second is $\mathrm{CH}_{3} \mathrm{Br}$ which was $14.7 \%$ (1.14 ppt) lower than the NOAA-ESRL reference. This discrepancy could be caused by a decrease of mixing ratio with altitude in the troposphere as reported by Blake et al. (1997), by its latitudinal gradient or by a decrease due to instability within this particular sample container. The third substance showing a difference to NOAA-ESRL values was $\mathrm{CH}_{3} \mathrm{Cl}$. We found $601 \mathrm{ppt}$ of $\mathrm{CH}_{3} \mathrm{Cl}$ at $15 \mathrm{~km}$ while the globally averaged mixing ratio at ground levels in June 2005 was 538 ppt (source: http://www.esrl.noaa.gov/gmd/). One possible explanation 
Table 1. Measured compounds grouped by substance classes with source of calibration and detection limits. All NOAA calibrations originate from a calibrated container obtained from NOAA-ESRL and were transferred to an internal secondary calibration container used for sample measurements. The years indicate the revision of the calibration scale. The University of East Anglia (UEA), UK calibrations originate from a direct cross-comparison of that secondary container with an internal secondary UEA calibration container for $\mathrm{C}_{2} \mathrm{HCl}_{3}$ and $\mathrm{C}_{2} \mathrm{Cl}_{4}$. Four substances were calibrated using air samples from UEA which were measured twice at both institutes: F115, F114, F114a and H2402. The remaining substances - 1,2-dichloroethane and F124 - were quantified via a cross-comparison with a container calibrated by E. Atlas of the University of Miami, USA which is owned by the Max-Planck-Institute for Chemistry in Mainz, GER.

\begin{tabular}{|c|c|c|c|}
\hline Substance group & Formula (name) & Calibration source & $\begin{array}{l}\text { Detection } \\
\text { limit [ppt] }\end{array}$ \\
\hline \multirow[t]{6}{*}{ CFCs } & $\mathrm{CF}_{2} \mathrm{ClCF}_{3}(\mathrm{~F} 115)$ & UEA & 0.4 \\
\hline & $\mathrm{CF}_{2} \mathrm{Cl}_{2}(\mathrm{~F} 12)$ & NOAA-2001 & 0.3 \\
\hline & $\mathrm{CF}_{2} \mathrm{ClCF}_{2} \mathrm{Cl}(\mathrm{F} 114)$ & UEA & 0.2 \\
\hline & $\mathrm{CFCl}_{2} \mathrm{CF}_{3}(\mathrm{~F} 114 \mathrm{a})$ & UEA & 0.1 \\
\hline & $\mathrm{CFCl}_{3}(\mathrm{~F} 11)$ & NOAA-1993 & 0.1 \\
\hline & $\mathrm{CFCl}_{2} \mathrm{CF}_{2} \mathrm{Cl}(\mathrm{F} 113)$ & NOAA-2002 & 0.1 \\
\hline \multirow[t]{4}{*}{ Halons } & $\mathrm{CF}_{3} \mathrm{Br}(\mathrm{H} 1301)$ & NOAA-2006 & 0.4 \\
\hline & $\mathrm{CF}_{2} \mathrm{ClBr}(\mathrm{H} 1211)$ & NOAA-2006 & 0.6 \\
\hline & $\mathrm{CF}_{2} \mathrm{BrCF}_{2} \mathrm{Br}(\mathrm{H} 2402)$ & UEA & 0.2 \\
\hline & $\mathrm{CF}_{2} \mathrm{Br}_{2}(\mathrm{H} 1202)^{*}$ & UEA & 0.002 \\
\hline \multirow[t]{4}{*}{ HCFCs } & $\mathrm{CHF}_{2} \mathrm{Cl}(\mathrm{F} 22)$ & NOAA-2006 & 0.5 \\
\hline & $\mathrm{CHFClCF}_{3}(\mathrm{~F} 124)$ & U. Miami & 0.4 \\
\hline & $\mathrm{CH}_{3} \mathrm{CF}_{2} \mathrm{Cl}(\mathrm{F} 142 \mathrm{~b})$ & NOAA-1994 & 0.3 \\
\hline & $\mathrm{CH}_{3} \mathrm{CFCl}_{2}(\mathrm{~F} 141 \mathrm{~b})$ & NOAA-1994 & 0.3 \\
\hline \multirow{4}{*}{$\begin{array}{l}\text { Longer-lived } \\
\text { chloro- and } \\
\text { bromocarbons }\end{array}$} & $\mathrm{CH}_{3} \mathrm{Cl}$ & NOAA-2003 & 19 \\
\hline & $\mathrm{CCl}_{4}$ & NOAA-2002 & 0.2 \\
\hline & $\mathrm{CH}_{3} \mathrm{CCl}_{3}$ & NOAA-2003 & 0.3 \\
\hline & $\mathrm{CH}_{3} \mathrm{Br}$ & NOAA-2003 & 0.4 \\
\hline \multirow[t]{10}{*}{ VSLS } & $\mathrm{CH}_{2} \mathrm{Cl}_{2}$ & NOAA-1992 & 0.8 \\
\hline & $\mathrm{CHCl}_{3}$ & NOAA-1992 & 0.4 \\
\hline & $\mathrm{CH}_{2} \mathrm{ClCH}_{2} \mathrm{Cl}$ & U. Miami & 0.1 \\
\hline & $\mathrm{C}_{2} \mathrm{HCl}_{3}$ & UEA & 1.8 \\
\hline & $\mathrm{C}_{2} \mathrm{Cl}_{4}$ & UEA & 0.7 \\
\hline & $\mathrm{CH}_{2} \mathrm{BrCl}^{*}$ & UEA & 0.01 \\
\hline & $\mathrm{CHBrCl}_{2}^{*}$ & UEA & 0.0008 \\
\hline & $\mathrm{CHBr}_{2} \mathrm{Cl}^{*}$ & UEA & 0.001 \\
\hline & $\mathrm{CH}_{2} \mathrm{Br}_{2}^{*}$ & UEA & 0.001 \\
\hline & $\mathrm{CHBr}_{3}^{*}$ & UEA & 0.001 \\
\hline
\end{tabular}

* measured at the University of East Anglia (UEA)

could be that our correction of the drift in the containers was insufficient. However, the tropics are a source region of $\mathrm{CH}_{3} \mathrm{Cl}$. For instance Khalil and Rasmussen (1999) reported elevated surface mixing ratios in tropical regions and Gebhardt et al. (2008) found levels around $600 \mathrm{ppt}$ for $\mathrm{CH}_{3} \mathrm{Cl}$ in air samples taken at altitudes around $10 \mathrm{~km}$ above Surinam in October 2005. As $\mathrm{CH}_{3} \mathrm{Cl}$ is longer-lived in the atmosphere the observed elevated mixing ratio could e.g. originate from the rainforest without being influenced from local convection.

\subsection{Error bar calculations}

The error bars of the measured organic chlorine and bromine $\chi_{\text {org }}$ (see Sect. 4.1) include the $1 \sigma$ measurement uncertainties and the sample instability errors as calculated using Eq. (1) and weighting with the number of chlorine or bromine atoms contained in the respective substance.

$\chi_{\mathrm{org}}= \pm\left[\sum_{i} e_{s i, i}+\sqrt{\sum_{i}\left(\sigma_{s m, i}^{2}+\sigma_{c t, i}^{2}\right)}\right]$

The sample instability errors $e_{s i}$ (if observed) are systematic errors. For that reason they were summed up separately. Due 


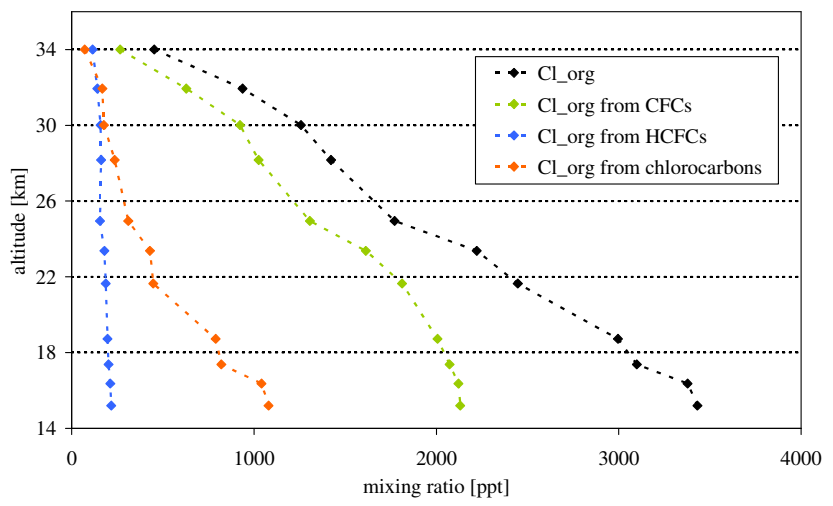

Fig. 2a. Total mixing ratios of chlorine from organic source gases $\left(\mathrm{Cl}_{\text {org }}\right)$ and contributions of substance subgroups to that total in the different altitudes. The data for chlorocarbons include VSLS and non-fluorinated longer-lived chlorocarbons (see Tables). Chlorine from $\mathrm{H} 1211$ is only included in the $\mathrm{Cl}_{\text {org }}$. The error bars are less than the size of the symbols and include the $1 \sigma$ uncertainties of the measurements and the sample instability errors if observed.

to the limited amount of air available from the containers the samples where measured only twice. Thus $\sigma_{s m}$ is the standard deviation of the calibration standard on the measuring day. We used a secondary standard for the measurements. Therefore $\sigma_{c t}$ is the standard deviation from the calibration of that standard. As $\sigma_{s m}$ and $\sigma_{c t}$ are statistic errors the square root of the sum of the squares can be taken. Calibration uncertainties are not included in the error bars.

The error of the estimated total chlorine/bromine $\chi_{\text {total }}$ (see Sect. 4.2) was derived as the sum of the measurement uncertainties of $\mathrm{CH}_{3} \mathrm{Cl}$, F115, F114, F114a, F124, H1202, H2402 and the VSLS according to Eq. (1) and $\chi_{\text {NOAA }}$ - the standard deviations of the global mixing ratios for all other substances averaged over 2001 as provided by NOAA-ESRL (source: http://www.esrl.noaa.gov/gmd/). Both errors were calculated with respect to the number of chlorine/bromine atoms. The error of the inorganic chlorine/bromine $\chi_{y}$ is the sum of $\chi_{\text {org }}$ and $\chi_{\text {NOAA }}$. Please note that the influence of our measurements on $\mathrm{Cl}_{\mathrm{y}}, \mathrm{Br}_{\mathrm{y}}$ and the corresponding error bars decreases with altitude. Changes in $\mathrm{Cl}_{\mathrm{y}} / \mathrm{Br}_{\mathrm{y}}$ due to mean age of air calculations carried out with $\mathrm{SF}_{6}$ mixing ratios $\pm 2 \sigma$ of the measured values were also calculated and ranged from -6 to +2 ppt for $\mathrm{Cl}_{\mathrm{y}}$ and from -0.03 to +0.03 ppt for $\mathrm{Br}_{\mathrm{y}}$. We also estimated $\mathrm{Cl}_{\mathrm{y}} / \mathrm{Br}_{\mathrm{y}}$ changes derived from different width parameterisations of the age distribution function. The $\mathrm{Cl}_{\mathrm{y}}$ changes ranged from -8 to $+7 \mathrm{ppt}$ while $\mathrm{Br}_{\mathrm{y}}$ varied between -0.04 and $+0.12 \mathrm{ppt}$. We conclude that both uncertainties have little influence on the derived $\mathrm{Cl}_{\mathrm{y}} / \mathrm{Br}_{\mathrm{y}}$. Uncertainties which could originate from hemispheric mixing ratio gradients were not estimated.

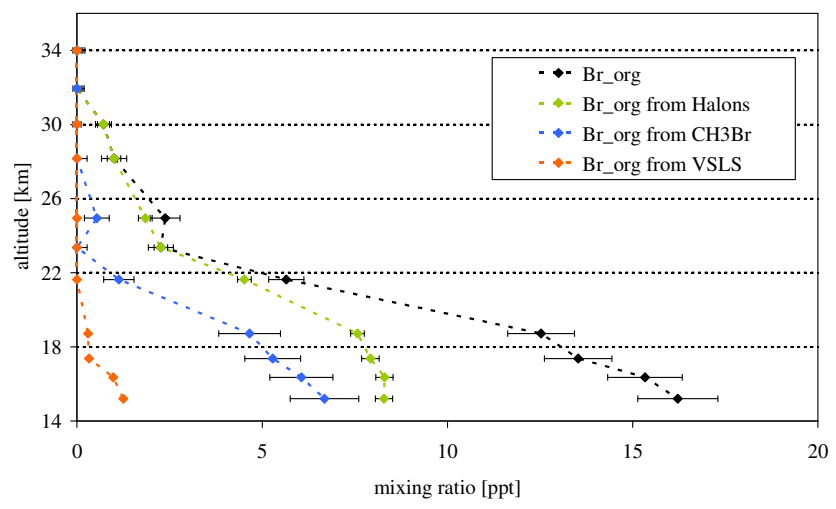

Fig. 2b. The same as Fig. 2a but for bromine.

\section{Results and discussion}

\subsection{Organic chlorine and bromine}

During the balloon flight the cold-point tropopause was located at $16.8 \mathrm{~km}$ ( $385 \mathrm{~K}$ potential temperature). The two lowest samples were collected at $15.2 \mathrm{~km}(359 \mathrm{~K})$ and $16.36 \mathrm{~km}(371 \mathrm{~K})$ within the TTL. For all further discussions, we will use the TTL definition given by Gettelman and Forster (2002). According to this definition the TTL extends from the minimum potential temperature lapse rate to the cold point. Air parcels reaching the level of zero radiative heating, which is located at $15 \pm 0.5 \mathrm{~km}$ and $360 \mathrm{~K}$, are expected to be transported to the stratosphere (Gettelman et al., 2004). We will assume that the signatures of both samples originating from the TTL are very likely to be injected into the stratosphere. However, due to the high variability of VSLS in the troposphere and since many processes influence the composition of the tropical region around $15 \mathrm{~km}$ (see e.g. Tuck et al., 2004) we do not claim global significance for the mixing ratios found in the lowest altitude sample. On the other hand the air sampled at $16.4 \mathrm{~km}$ was located very close to the upper limit of the TTL and thus its chemical composition should be more representative for the inner tropics (Gettelman and Forster, 2002).

The total halogen mixing ratios and the contribution of the source gas subgroups at the different altitudes are shown in Fig. 2a for chlorine and $2 \mathrm{~b}$ for bromine. Please note, that the samples at 28 and $32 \mathrm{~km}$ altitude could not be measured at the UEA due to insufficient amount of air remaining in the containers. Thus, the values for total organic bromine and chlorine in these samples do not include the mixing ratios of $\mathrm{H} 1202, \mathrm{CH}_{2} \mathrm{BrCl}, \mathrm{CHBrCl}_{2}, \mathrm{CH}_{2} \mathrm{Br}_{2}, \mathrm{CHBr}_{2} \mathrm{Cl}$ and $\mathrm{CHBr}_{3}$ (see Tables 3 and 4). Table 2 shows the total halogen mixing ratios corresponding to the values shown in Fig. $2 a$ and $b$ and the altitude range, over which the air has been sampled into each container during the slow descent of the balloon. Longer-lived halocarbon data from the flight are shown in Table 3 while in Table 4 the mixing ratios of the VSLS for the 
Table 2. The measured total organic halogen mixing ratios with $1 \sigma$ measurement and sample instability uncertainties in ppt. All samples where taken during balloon descent and represent altitude ranges, while $\Theta$ is the potential temperature. Also shown are the derived inorganic mixing ratios in ppt. Their errors include our measurement uncertainties as well as the uncertainties from NOAA-ESRL ground-based measurements.

\begin{tabular}{lrrrrrrrrrr}
\hline $\begin{array}{l}\text { Altitude } \\
{[\mathrm{km}]}\end{array}$ & $\begin{array}{r}\text { Range } \\
{[\mathrm{km}]}\end{array}$ & $\Theta[\mathrm{K}]$ & $\mathrm{Cl}_{\text {org }}$ & $\begin{array}{c}\mathrm{Cl}_{\text {org }} \\
\text { error }\end{array}$ & $\mathrm{Br}_{\text {org }}$ & $\begin{array}{r}\mathrm{Br}_{\text {org }} \\
\text { error }\end{array}$ & $\mathrm{Cl}_{\mathrm{y}}$ & $\begin{array}{c}\mathrm{Cl}_{\mathrm{y}} \\
\text { error }\end{array}$ & $\mathrm{Br}_{\mathrm{y}}$ & $\begin{array}{c}\mathrm{Br}_{\mathrm{y}} \\
\text { error }\end{array}$ \\
\hline 34.00 & 1.5 & 1036.7 & 452 & 10 & 0.0 & 0.2 & 3062 & 11 & 17.5 & 0.4 \\
$31.94^{*}$ & 1.1 & 907.8 & 937 & 12 & 0.0 & 0.2 & 2558 & 13 & 17.5 & 0.4 \\
30.01 & 0.7 & 819.7 & 1257 & 12 & 0.7 & 0.2 & 2228 & 13 & 16.7 & 0.4 \\
$28.17^{*}$ & 0.5 & 751.1 & 1422 & 12 & 1.0 & 0.3 & 2063 & 14 & 16.4 & 0.5 \\
24.95 & 0.7 & 636.5 & 1771 & 14 & 2.4 & 0.4 & 1703 & 15 & 15.0 & 0.6 \\
23.37 & 0.9 & 577.8 & 2221 & 16 & 2.3 & 0.3 & 1244 & 18 & 15.0 & 0.5 \\
21.64 & 0.6 & 521.2 & 2447 & 18 & 5.7 & 0.5 & 1008 & 19 & 11.6 & 0.6 \\
18.72 & 0.4 & 437.7 & 2996 & 24 & 12.5 & 0.9 & 444 & 26 & 4.6 & 1.1 \\
17.37 & 0.3 & 402.5 & 3099 & 22 & 13.5 & 0.9 & 340 & 24 & 3.6 & 1.1 \\
16.36 & 0.6 & 371.1 & 3377 & 29 & 15.3 & 1.0 & 55.6 & 30 & 1.8 & 1.2 \\
15.20 & 0.5 & 359.2 & 3431 & 30 & 16.2 & 1.1 & -0.2 & 31 & 0.9 & 1.2 \\
\hline
\end{tabular}

* Not measured at the University of East Anglia - several substances are not included (see Table 1).

Table 3. Observed mixing ratios of CFCs, HCFCs and longer-lived non-fluorinated chloro- and bromocarbons in ppt (n.d. - not detected; n.m. - not measured). The mixing ratios of $\mathrm{CH}_{3} \mathrm{Cl}$ and $\mathrm{CCl}_{4}$ were shifted due to drifts in the sample containers.

\begin{tabular}{|c|c|c|c|c|c|c|c|c|c|c|c|}
\hline \multirow[b]{2}{*}{ Substance } & \multicolumn{11}{|c|}{ Altitude $[\mathrm{km}] /$ Mixing ratio $[\mathrm{ppt}]$} \\
\hline & 15.20 & 16.36 & 17.37 & 18.72 & 21.64 & 23.37 & 24.95 & 28.17 & 30.01 & 31.94 & 34.00 \\
\hline $\mathrm{CF}_{2} \mathrm{Cl}_{2}(\mathrm{~F} 12)$ & 538.7 & 537.8 & 530.4 & 523.8 & 492.8 & 465.8 & 435.5 & 375.0 & 353.4 & 252.1 & 103.9 \\
\hline $\mathrm{CFCl}_{3}(\mathrm{~F} 11)$ & 254.8 & 252.1 & 243.9 & 233.7 & 187.9 & 143.6 & 87.54 & 28.04 & 14.32 & 1.55 & n.d. \\
\hline $\mathrm{CF}_{2} \mathrm{ClCFCl}_{2}(\mathrm{~F} 113)$ & 80.90 & 80.89 & 78.05 & 70.76 & 72.49 & 68.90 & 43.57 & 49.87 & 43.85 & 27.21 & 7.84 \\
\hline $\mathrm{CF}_{2} \mathrm{ClCF}_{2} \mathrm{Cl}(\mathrm{F} 114)$ & 16.65 & 16.66 & 16.58 & 16.36 & 16.39 & 16.12 & 15.06 & 15.5 & 15.35 & 14.92 & 13.28 \\
\hline $\mathrm{C}_{2} \mathrm{~F}_{5} \mathrm{Cl}(\mathrm{F} 115)$ & 8.82 & 8.97 & 8.76 & 8.94 & 8.73 & 8.48 & 8.48 & 8.38 & 8.29 & 8.14 & 7.82 \\
\hline $\mathrm{CF}_{3} \mathrm{CFCl}_{2}(\mathrm{~F} 114 \mathrm{a})$ & 2.05 & 2.01 & 1.94 & 1.69 & 1.70 & 1.58 & 1.48 & 1.25 & 1.19 & n.d. & n.d. \\
\hline $\mathrm{CHF}_{2} \mathrm{Cl}(\mathrm{F} 22)$ & 164.0 & 160.3 & 152.6 & 151.1 & 142.2 & 138.6 & 125.1 & 130.5 & 130.8 & 121.2 & 102.9 \\
\hline $\mathrm{CH}_{3} \mathrm{CFCl}_{2}(\mathrm{~F} 141 \mathrm{~b})$ & 18.05 & 17.35 & 16.65 & 15.01 & 14.62 & 13.17 & 8.76 & 8.73 & 7.45 & 3.98 & 0.87 \\
\hline $\mathrm{CH}_{3} \mathrm{CF}_{2} \mathrm{Cl}(\mathrm{F} 142 \mathrm{~b})$ & 15.27 & 15.04 & 14.39 & 14.31 & 13.66 & 13.18 & 11.69 & 12.14 & 12.02 & 11.26 & 9.65 \\
\hline $\mathrm{CHFClCF}_{3}(\mathrm{~F} 124)$ & 1.68 & 1.64 & 1.55 & 1.40 & 1.38 & 1.13 & 0.69 & 0.73 & 0.69 & 0.72 & 0.43 \\
\hline $\mathrm{CH}_{3} \mathrm{Cl}$ & 600.9 & 570.8 & 459.8 & 427.3 & 182.9 & 254.6 & 241.4 & 224.0 & 171.0 & 164.8 & 71.84 \\
\hline $\mathrm{CCl}_{4}$ & 93.50 & 93.70 & 75.52 & 77.47 & 58.54 & 37.58 & 12.51 & 1.63 & n.d. & n.d. & n.d. \\
\hline $\mathrm{CH}_{3} \mathrm{CCl}_{3}$ & 19.22 & 19.50 & 18.08 & 16.11 & 9.96 & 7.98 & 4.82 & n.d. & 0.61 & n.d. & n.d. \\
\hline $\mathrm{CH}_{3} \mathrm{Br}$ & 6.68 & 6.05 & 5.28 & 4.66 & 1.13 & n.d. & 0.54 & n.d. & n.d. & n.d. & n.d. \\
\hline $\mathrm{CF}_{2} \mathrm{ClBr}(\mathrm{H} 1211)$ & 4.17 & 4.13 & 3.9 & 3.89 & 1.93 & n.d. & n.d. & n.d. & n.d. & n.d. & n.d. \\
\hline $\mathrm{CF}_{3} \mathrm{Br}(\mathrm{H} 1301)$ & 3.19 & 3.18 & 3.25 & 3.01 & 2.55 & 2.24 & 1.84 & 1.00 & 0.71 & n.d. & n.d. \\
\hline $\mathrm{CF}_{2} \mathrm{BrCF}_{2} \mathrm{Br}(\mathrm{H} 2402)$ & 0.43 & 0.46 & 0.35 & 0.30 & n.d. & n.d. & n.d. & n.d. & n.d. & n.d. & n.d. \\
\hline $\mathrm{CF}_{2} \mathrm{Br}_{2}(\mathrm{H} 1202)$ & 0.034 & 0.035 & 0.029 & 0.031 & 0.018 & 0.010 & 0.002 & n.m. & n.d. & n.m. & n.d. \\
\hline
\end{tabular}

four lowest altitude samples can be found. $\mathrm{C}_{2} \mathrm{Cl}_{4}(1.02 \mathrm{ppt})$ and $\mathrm{CHBr}_{3}(0.016 \mathrm{ppt})$ could only be detected in the sample collected at $15.2 \mathrm{~km}$ and are therefore not listed. $\mathrm{CHClBr}_{2}$ and $\mathrm{C}_{2} \mathrm{HCl}_{3}$ were below detection limit (see Table 1) for all samples.

In the TTL at $15.2 \mathrm{~km}$ we found $3431 \pm 30 \mathrm{ppt}$ of chlorine from organic substances. About $62.1 \%$ of the chlorine is present in the form of CFCs, while HCFCs con- tributed $6.3 \%$, longer-lived non-fluorinated chlorocarbons $30.1 \%$ and $\mathrm{H} 12110.1 \%$. Only $1.4 \%$ (47.1 $\pm 5.7 \mathrm{ppt})$ of chlorine came from VSLS, whereby the main contribution was from $\mathrm{CH}_{2} \mathrm{Cl}_{2}(22.4 \pm 1.8 \mathrm{ppt})$. The estimated tropical upper tropospheric mixing ratio in Table 2-2 of Law and Sturges (2007) is $55 \mathrm{ppt}$ (range: 52-60 ppt) for total chlorine from VSLS including $1.5 \mathrm{ppt}$ from chloroethane which is the only source gas mentioned by Law and Sturges (2007) that 
Table 4. Observed mixing ratios of VSLS in ppt. $\mathrm{C}_{2} \mathrm{Cl}_{4}(1.0 \mathrm{ppt})$ and $\mathrm{CHBr}_{3}(0.016 \mathrm{ppt})$ were only detected at $15.2 \mathrm{~km}$ and are not listed. $\mathrm{CHClBr}_{2}$ and $\mathrm{C}_{2} \mathrm{HCl}_{3}$ were below detection limit (n.d. - not detected). The mixing ratios of $\mathrm{CH}_{2} \mathrm{ClCH}_{2} \mathrm{Cl}$ were shifted due to drifts in the sample containers.

\begin{tabular}{lllllll}
\hline $\begin{array}{l}\text { Altitude } \\
{[\mathrm{km}]}\end{array}$ & $\begin{array}{l}\mathrm{CH}_{2} \mathrm{Cl}_{2} \\
{[\mathrm{ppt}]}\end{array}$ & $\begin{array}{l}\mathrm{CHCl}_{3} \\
{[\mathrm{ppt}]}\end{array}$ & $\begin{array}{l}\mathrm{CH}_{2} \mathrm{ClCH}_{2} \mathrm{Cl} \\
{[\mathrm{ppt}]}\end{array}$ & $\begin{array}{l}\mathrm{CH}_{2} \mathrm{BrCl} \\
{[\mathrm{ppt}]}\end{array}$ & $\begin{array}{l}\mathrm{CHBrCl}_{2} \\
{[\mathrm{ppt}]}\end{array}$ & $\begin{array}{l}\mathrm{CH}_{2} \mathrm{Br}_{2} \\
{[\mathrm{ppt}]}\end{array}$ \\
\hline 18.72 & 1.9 & n.d. & n.d. & 0.020 & n.d. & 0.139 \\
17.37 & 2.3 & n.d. & n.d. & 0.030 & n.d. & 0.147 \\
16.36 & 9.8 & 1.9 & 5.6 & 0.090 & 0.010 & 0.439 \\
15.20 & 11.2 & 2.7 & 6.2 & 0.087 & 0.017 & 0.549 \\
\hline
\end{tabular}

was not quantified in our study. Taking this into account, Law and Sturges (2007) derived an average of 53.5 ppt (range: $\sim 51-58 \mathrm{ppt}$ ) for the remaining chlorinated VSLS in the tropical upper troposphere. This agrees with our findings within the given error bars. At $16.4 \mathrm{~km}$ we found $3377 \pm 30 \mathrm{ppt}$ of organic chlorine with $1.1 \%(36.6 \pm 5.1 \mathrm{ppt})$ from VSLS. As described above the air mass sampled is very likely to have been transported into the stratosphere because of its location above the level of zero radiative heating. Above the tropopause the total organic chlorine decreases with altitude due to conversion into inorganic species. At the highest flight altitude $(34 \mathrm{~km})$ all short lived source gases were depleted to values below our detection limits and the remaining organic chlorine was $452 \pm 10$ ppt. This corresponds to about $13 \%$ of the amount observed in the TTL.

Organic bromine at $15.2 \mathrm{~km}$ was $16.2 \pm 1.1 \mathrm{ppt}$ with $51 \%$ present in the form of halons, $41 \%$ in the form of $\mathrm{CH}_{3} \mathrm{Br}$ and $8 \%(1.25 \pm 0.08 \mathrm{ppt})$ originating from the five brominated VSLS listed in Table 4. In $16.4 \mathrm{~km}$ we found a mixing ratio of bromine from VSLS of about $0.98 \pm 0.08 \mathrm{ppt}(6 \%)$. Both VSLS contributions are substantially lower than the global tropical upper tropospheric mixing ratio of $3.5 \mathrm{ppt}$ (range: 3.1-4.0 ppt) estimated by Law and Sturges (2007). In particular we found $\mathrm{CH}_{2} \mathrm{Br}_{2}$ with a mixing ratio of $0.55 \pm 0.001 \mathrm{ppt}$ at $15.2 \mathrm{~km}$ to be the dominant very shortlived source gas while the $\mathrm{CHBr}_{3}$ mixing ratio was very low $(0.016 \pm 0.005 \mathrm{ppt})$ in this sample. Sinnhuber and Folkins (2006) presented higher $\mathrm{CHBr}_{3}$ mixing ratios of up to about $0.2 \mathrm{ppt}$ above $15 \mathrm{~km}$ in the tropics. This is not in contrast with our findings as the VSLS have a high atmospheric variability. Moreover the mixing ratios agree with previous observations of Schauffler et al. (1998), who found about $0.5 \mathrm{ppt}$ of $\mathrm{CH}_{2} \mathrm{Br}_{2}$ in the inner tropics at $15 \mathrm{~km}$ altitude while $\mathrm{CHBr}_{3}$ was near or below detection limit. Also in agreement with Schauffler et al. (1998) we observed $\mathrm{CH}_{2} \mathrm{Br}_{2}$ and $\mathrm{CH}_{2} \mathrm{Cl}_{2}$ up to $18.7 \mathrm{~km}$. In common with chlorine, the organic bromine mixing ratio decreased with altitude in the stratosphere, but in contrast to chlorine no brominated organic substances were detected in both samples collected above $30 \mathrm{~km}$.

\subsection{Inorganic chlorine and bromine}

Inorganic chlorine $\left(\mathrm{Cl}_{\mathrm{y}}\right)$ and bromine $\left(\mathrm{Br}_{\mathrm{y}}\right)$ can be calculated as the difference between the total amount of halogen which initially entered the stratosphere and the total measured halogen amount from organic substances. The stratospheric entry mixing ratio for each substance must be known for this calculation. As the air is ascending very slowly in the TTL and above the entry mixing ratio needs to be corrected for tropospheric time trends and how the air masses are mixed on their transport upwards. We used a procedure for the calculation of the mean stratospheric entry mixing ratios described by Engel et al. (2002). First for every sample the mean age of air was derived from measured $\mathrm{SF}_{6}$ mixing ratios. The mean age of air is a measure of the stratospheric residence time of an air parcel. According to Hall and Plumb, 1994 every stratospheric air parcel consists of a large number of irreversibly mixed parcels and its age can be described with a distribution function. The mean age of air is the centre of this function. As we can only calculate the mean age from our measurements we used a width parameterisation according to Engel et al. (2002) to derive the distribution function. Using this function and global tropospheric time trends we calculated the amount of trace gas that would be present without chemical degradation i.e. the mean entrance mixing ratio. Global tropospheric trend data was taken from NOAA-ESRL. For substances without these trend functions available a simplified procedure was applied. First we assumed that our sample at $15.2 \mathrm{~km}$ is reflecting the mean stratospheric entrance mixing ratio. For $\mathrm{CH}_{3} \mathrm{Cl}, \mathrm{H} 2402$ and the VSLS which show no systematic or significant global trend we took the observed mixing ratio in that sample as the stratospheric entry mixing ratio for all other samples. We assumed the same for F115, F114, F114a, F124 and H1202 but additionally corrected for their tropospheric trend to reconstruct the tropospheric time series backwards (extrapolated linear trend between 2003 and 2004 as reported in Table 1-2 of Clerbaux and Cunnold, 2007). The derived $\mathrm{Cl}_{\mathrm{y}}$ and $\mathrm{Br}_{\mathrm{y}}$ and the corresponding total chlorine and bromine from the entrance mixing ratios are depicted in Fig. 3. Please note, that the contribution from a product gas injection as derived by Law and 


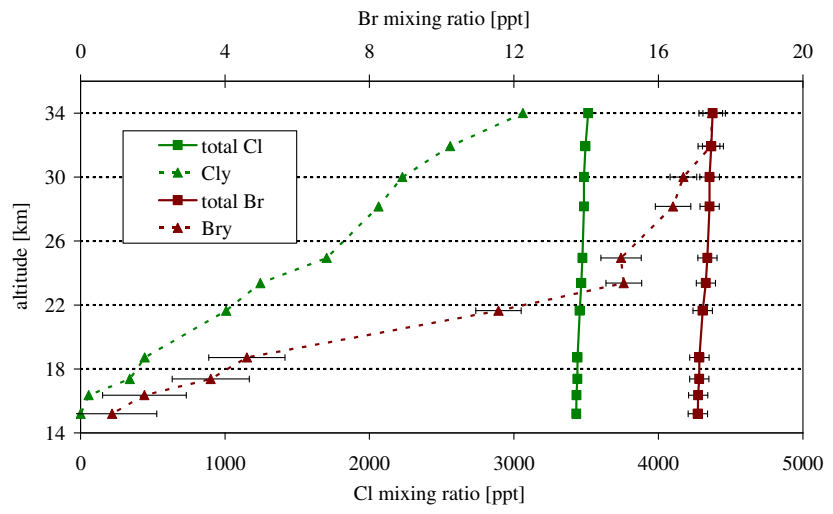

Fig. 3. The derived inorganic chlorine $\left(\mathrm{Cl}_{\mathrm{y}}\right)$ and bromine $\left(\mathrm{Br}_{\mathrm{y}}\right)$ and the corresponding total $\mathrm{Cl}$ and $\mathrm{Br}$ for the different altitudes. The error bars are the same as in Table 2 and less than the size of the symbols for chlorine.

Sturges (2007) (40-50 ppt of chlorine) was not considered in our $\mathrm{Cl}_{\mathrm{y}}$ calculation. For comparison with the measurements $\mathrm{Cl}_{\mathrm{y}}$ and $\mathrm{Br}_{\mathrm{y}}$ are also shown in Table 2 .

The derived $\mathrm{Cl}_{\mathrm{y}}$ at $15.2 \mathrm{~km}$ is zero within the error bars $(-0.2 \pm 31 \mathrm{ppt})$ and proves the good agreement with most global tropospheric mixing ratio observations by NOAAESRL. Notable is the sharp increase to $340 \pm 24$ ppt just above the tropopause, which is mostly due to the rapid decomposition of $\mathrm{CH}_{3} \mathrm{Cl}$ and $\mathrm{CCl}_{4}$.

For $\mathrm{Br}_{\mathrm{y}}$ low mixing ratios of $1.8 \pm 1.2 \mathrm{ppt}$ at $16.4 \mathrm{~km}$ and $3.6 \pm 1.1 \mathrm{ppt}$ at $17.4 \mathrm{~km}$ were inferred. At $34 \mathrm{~km}$, where all organic bromine is destroyed we derived $17.5 \pm 0.4 \mathrm{ppt}$ of $\mathrm{Br}_{\mathrm{y}}$ based on the organic bromine from ground-based NOAA observations and our measurements in the TTL. During another balloon flight on the $17 \mathrm{June} 2005 \mathrm{BrO}$ was measured by the University of Heidelberg using Differential Optical Absorption Spectroscopy (DOAS). By using a photochemical model and correcting for the $\mathrm{BrO} / \mathrm{Br}_{\mathrm{y}}$ ratio they derived 21.5 $2.5 \mathrm{ppt}$ of $\mathrm{Br}_{\mathrm{y}}$ at $33 \mathrm{~km}$ (Dorf, 2005; Dorf et al., 2008). Thus, both calculations differ by $4.0 \mathrm{ppt}$ but the significant uncertainty range of $\pm 2.9 \mathrm{ppt}$ should be noted. A difference was also found in earlier studies (e.g. Salawitch et al., 2005; Feng et al., 2006; Law and Sturges, 2007) and a number of causes could account for it. Our observations and calculations are mainly based on the NOAA calibration scale. For instance the other large global monitoring network AGAGE found 0.72 ppt higher bromine from H1211 and H1301 in 2004 (see http://agage.eas.gatech.edu/ or Table 1-2 in Clerbaux and Cunnold, 2007) probably reflecting differences in absolute calibration scales. This could explain a part of the difference in the derived $\mathrm{Br}_{\mathrm{y}}$ values. Another possibility is that the observed TTL region did not represent global VSLS mean entrance mixing ratios to the stratosphere. An injection of higher amounts of source gases at different seasons, latitudes or longitudes due to the local influence of convection might have lead to higher $\mathrm{Br}_{\mathrm{y}}$ (see e.g. Levine et al., 2007).

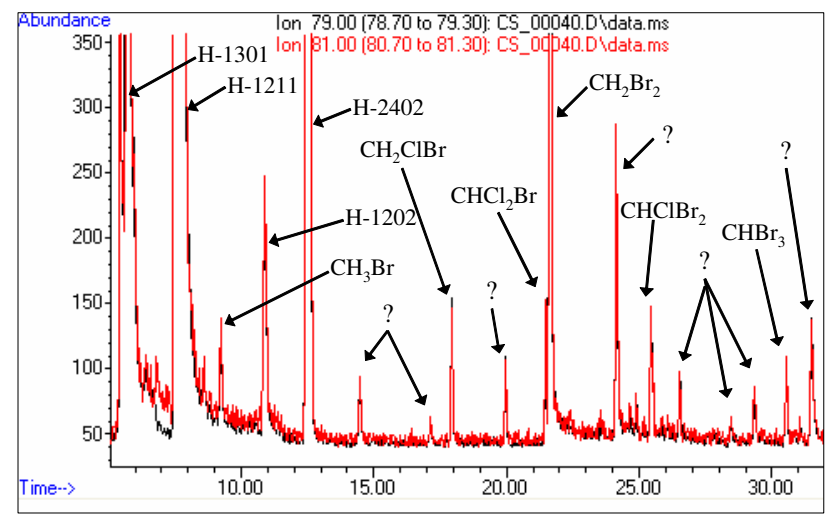

Fig. 4. The chromatogram of the air sample collected at $15.2 \mathrm{~km}$ altitude as analysed with GC-NICI-MS at the University of East Anglia. The displayed ions with a mass/charge ratio of 79 and 81 in a ratio of $1: 1$ are specific for bromine containing species which indicates that at least eight additional brominated substances are present in the tropical tropopause region. The peaks at about 14.5, 17, 20 and $26.5 \mathrm{~min}$ retention time are suggested to belong to $\mathrm{C}_{2} \mathrm{H}_{5} \mathrm{Br}$ (bromoethane), $\mathrm{CF}_{3} \mathrm{CHClBr}$ (halothane), $\mathrm{C}_{3} \mathrm{H}_{7} \mathrm{Br}$ (npropyl bromide) and $\mathrm{CH}_{2} \mathrm{BrCH}_{2} \mathrm{Br}$ (1,2-dibromoethane) but four further unidentified brominated compounds remain.

Especially bromoform was found to be higher in other studies (Sinnhuber and Folkins, 2006; Law and Sturges, 2007). We could assume that the $3.5 \mathrm{ppt}$ of bromine from VSLS in the upper tropical troposphere as estimated by Law and Sturges (2007) are more representative for air entering the stratosphere. If we calculate $\mathrm{Br}_{\mathrm{y}}$ using this VSLS amount we find $19.75 \mathrm{ppt}$ of $\mathrm{Br}_{\mathrm{y}}$ which agrees with the $21.5 \pm 2.5 \mathrm{ppt}$ derived from $\mathrm{BrO}$ (Dorf, 2005; Dorf et al., 2008) even without deriving error bars.

A direct product gas injection as proposed by Ko et al. (1997) could also cause the difference in $\mathrm{Br}_{\mathrm{y}}$ by bringing inorganic bromine species contained in the upper tropospheric aerosol (Murphy and Thompson, 2000) or in gaseous form into the stratosphere. Another option is the presence of additional brominated organic substances. As shown in Fig. 4 we have found substances showing signals at ions with $\mathrm{m} / \mathrm{z} 79$ and 81 (the two stable isotopes of bromine) in the NICI chromatogram of the sample taken at $15.2 \mathrm{~km}$ altitude. We suggest four of these signals to belong to $\mathrm{C}_{2} \mathrm{H}_{5} \mathrm{Br}$ (bromoethane), $\mathrm{CF}_{3} \mathrm{CHClBr}$ (halothane), $\mathrm{C}_{3} \mathrm{H}_{7} \mathrm{Br}$ (n-propyl bromide) and $\mathrm{CH}_{2} \mathrm{BrCH}_{2} \mathrm{Br}$ (1,2-dibromoethane) but at least four further unidentified signals remain. Please note, that in NICI mode the size of a peak is not indicative for its concentration. For instance, in Fig. $4 \mathrm{CH}_{3} \mathrm{Br}$ appears as a small peak, but is more abundant than H1211. Some of the peaks were also present in samples taken at higher altitudes. These are strong indications for a further contribution from organic source gases to stratospheric bromine. 


\section{Conclusions}

Our study adds to the very few data available on VSLS in the tropical upper troposphere and lower stratosphere. From our measurements of 28 chloro- and bromocarbons including ten very short-lived substances we derived a VSLS contribution of $6-8 \%(0.98-1.25 \mathrm{ppt})$ to total organic bromine and $1.1-1.4 \%$ (36.6-47.1 ppt) to total organic chlorine entering the stratosphere above Brazil in June 2005. In addition we have found strong indications for the presence of additional bromine source gases in this region. Identification and quantification of these substances is crucial for future estimates of stratospheric bromine. We derived $\mathrm{Cl}_{\mathrm{y}}$ and $\mathrm{Br}_{\mathrm{y}}$ values based on ground-based observations from NOAA-ESRL and our measurements. $\mathrm{Br}_{\mathrm{y}}$ was calculated to be $17.5 \pm 0.4 \mathrm{ppt}$ in $34 \mathrm{~km}$ altitude which is in disagreement with $\mathrm{Br}_{\mathrm{y}}$ derived from quasi-simultaneous observations of $\mathrm{BrO}$ (Dorf, 2005; Dorf et al., 2008). An additional source of stratospheric bromine is a likely explanation in order to reconcile $\mathrm{Br}_{\mathrm{y}}$ derived from organic substances with $\mathrm{Br}_{\mathrm{y}}$ derived from the measurements of BrO. However, if calibration uncertainties and the atmospheric variability of VSLS are taken into account the derived $\mathrm{Br}_{\mathrm{y}}$ values could agree within their error bars. Further studies with higher spatial and temporal coverage and also a wider range of substances are needed to quantify the global influence of very short-lived brominated and chlorinated organic substances on stratospheric ozone. Differences in absolute calibration scales need to be resolved.

Acknowledgements. We would like to thank the European Space Agency, the Deutsches Zentrum fuer Luft- und Raumfahrt (project 50EE0016), the European Union (SCOUT-O3 project GOCE-CT-2003-505390) as well as the Deutsche Forschungsgesellschaft (CAWSES project EN 367/4) for funding, Elliot Atlas (University of Miami) in combination with Sarah Gebhardt (Max-Planck-Institute for Chemistry in Mainz) for calibration and Martyn Chipperfield for providing heating rates. Furthermore we appreciate the contribution of the anonymous referees, the work of the CNES balloon team who organised the campaign and of the NOAA-ESRL GMD teams who provided global tropospheric data.

Edited by: M. V. Roozendael

\section{References}

Apel, E. C., Calvert, J. G., and Fehsenfeld, F. C.: The Nonmethane Hydrocarbon Intercomparison Experiment (NOMHICE): Tasks 1 and 2, J. Geophys. Res., 99, 16 651-16 664, 1994.

Blake, D. R., Smith Jr., T. W., Chen, T.-Y., Whipple, W. J., and Rowland, F. S.: Effects of Biomass Burning on Summertime Nonmethane Hydrocarbon Concentrations in the Canadian Wetlands, J. Geophys. Res., 99, 1699-1719, 1994.

Blake, N. J., Blake, D. R., Chen, T. Y., Collins, J. E., Sachse, G. W., Anderson, B. E., and Rowland, F. S.: Distribution and seasonality of selected hydrocarbons and halocarbons over the Western
Pacific basin during PEM-West A and PEM-West B, J. Geophys. Res., 102, 28 315-28 331, 1997.

Buser, H. R.: Selective detection of brominated aromatic compounds using Gas Chromatography/Negative Chemical Ionization Mass Spectrometry, Anal. Chem., 58, 2913-2919, 1986.

Chipperfield, M. P.: Multiannual simulations with a threedimensional chemical transport model, J. Geophys. Res., 104, 1781-1805, 1999.

Clerbaux, C., Cunnold, D. M., Anderson, J., et al.: Halogenated Long-lived Compounds, Scientific assessment of ozone depletion: 2006, Global Ozone Research and Monitoring Project Report No. 50, Chapter 1, World Meteorological Organization, Geneva, 2007.

Dorf, M.: Investigation of inorganic stratospheric bromine using balloon-borne DOAS measurements and model simulations, Dissertation, University of Heidelberg, Germany, 2005.

Dorf, M., Butz, A., Camy-Peyret, C., Chipperfield, M. P., Kritten, L., and Pfeilsticker, K.: Bromine in the tropical troposphere and stratosphere as derived from balloon-borne $\mathrm{BrO}$ observations, Atmos. Chem. Phys. Discuss., 8, 12 999-13 015, 2008, http://www.atmos-chem-phys-discuss.net/8/12999/2008/.

Dvortsov, V. L., Geller, M. A., Solomon, S., Schauffler, S. M., Atlas, E. L., and Blake, D. R.: Rethinking reactive halogen budgets in the midlatitude lower stratosphere, Geophys. Res. Lett., 26(12), 1699-1702, 1999.

Engel, A., Schmidt, U., and Stachnik, R. A.: Partitioning between chlorine reservoir species deduced from observations in the Arctic winter stratosphere, J. Atmos. Chem, 27, 107-126, 1997.

Engel A., Strunk, M., Müller, M., Haase, H.-P., Poss, C., Levin, I., and Schmidt, U.: Temporal development of total chlorine in the high-latitude stratosphere based on reference distributions of mean age derived from $\mathrm{CO}_{2}$ and SF6, J. Geophys. Res., 107(D12), 4136, doi:10.1029/2001JD000584, 2002.

Feng, W., Chipperfield, M. P., Dorf, M., Pfeilsticker, K., and Ricaud, P.: Mid-latitude ozone changes: studies with a 3-D CTM forced by ERA-40 analyses, Atmos. Chem. Phys., 7, 2357-2369, 2007 , http://www.atmos-chem-phys.net/7/2357/2007/.

Finlayson-Pitts, B. J. and Pitts Jr. J. N.: Chemistry of the Upper and Lower Atmosphere - Theory, Experiments and Applications, Academic Press, San Diego, CA, USA and London, UK, 2000.

Gebhardt, S., Colomb, A., Hofmann, R., Williams, J., and Lelieveld, J.: Halogenated organic species over the tropical South American rainforest, Atmos. Chem. Phys., 8, 3185-3197, 2008 , http://www.atmos-chem-phys.net/8/3185/2008/.

Gettelman, A. and Forster, P. M. de F.: A climatology of the tropical tropopause layer, J. Meteorol. Soc. Jpn., 80(4B), 911-924, 2002.

Gettelman, A. and Forster, P. M. de F., Fujiwara, M., Fu, Q. Voemel, H., Gohar, L. K., Johanson, C., and Ammerman, M.: Radiation balance of the tropical tropopause layer, J. Geophys. Res., 109, D07103, doi:10.1029/2003JD004190, 2004.

Hall, T. M. and Plumb, R. A.: Age as a diagnostic of stratospheric transport, J. Geophys. Res., 99, 1059-1070, 1994.

Khalil, M. A. K. and Rasmussen, R. A.: Atmospheric methyl chloride, Atmos. Environ., 33, 1305-1321, 1999.

Ko, M. K. W., Sze, N. D., Scott, C. J., and Weisenstein, D. K.: On the relation between stratospheric chlorine/bromine loading and short-lived tropospheric source gases, J. Geopyhs. Res. 
102(D21), 25 507-25 518, 1997.

Langematz, U., Labitzke, K., and Reimer, E.: Synoptic analysis and trajectories during the MAP/GLOBUS campaign 1983, Planet. Space Sci., 35(5), 525-538, doi:10.1016/0032-0633(87)901206, 1987.

Law, K. S., Sturges, W. T., Blake, D. R., et al.: Halogenated very short-lived substances, Scientific assessment of ozone depletion: 2006, Global Ozone Research and Monitoring Project - Report No. 50, Chapter 2, World Meteorological Organization, Geneva, 2007.

Levine, J. G., Braesicke, P., Harris, N. R. P., Savage, N. H., and Pyle, J. A.: Pathways and timescales for troposphere-tostratosphere transport via the tropical tropopause layer and their relevance for very short lived substances, J. Geophys. Res., 112, D04308, doi:10.1029/2005JD006940, 2007.

Montzka, S. A., Fraser, P. J., Butler, J. H., et al.: Controlled substances and other source gases, Scientific assessment of ozone depletion: 2002, Global Ozone Research and Monitoring Project - Report No. 47, Chapter 1, World Meteorological Organization, Geneva, 2003.

Murphy, D. M. and Thompson, D. S.: Halogen ions and NO+ in the mass spectra of aerosols in the upper troposphere and lower stratosphere, Geophys. Res. Lett., 27, 3217-3220, 2000.

Nielsen, J. E. and Douglass, A. R.: A simulation of bromoform's contribution to stratospheric bromine, J. Geophys. Res., 106(D8), 8089-8100, 2001.

Pate, B., Jayanty, R. K. M., Peterson, M. R., and Evans, G. F.: Temporal Stability of Polar Organic Compounds in Stainless Steel Canisters, J. Air Waste Manage. Assoc., 42, 460-462, 1992.

Reimer, E. and Kaupp, H.: Source indentification of odour compounds using trajectories, Proc. ECOINFORMA 97, EcoInforma Press, Bayreuth, 572-577, 1997.

Salawitch, R. J., Weisenstein, D. K., Kovalenko, L. J., Sioris, C. E., Wennberg, P. O., Chance, K., Ko, M. K. W., and McLinden, C. A.: Sensitivity of ozone to bromine in the lower stratosphere, Geophys. Res. Lett., 32, L05811, doi:10.1029/2004GL021504, 2005.
Schauffler, S. M., Atlas, E. L., Flocke, F., Lueb, R. A., Stroud, V., and Travnicek, W.: Measurements of bromine containing organic compounds at the tropical tropopause, Geophys. Res. Lett., 25(3), 317-320, 1998.

Schauffler, S. M., Atlas, E. L., Blake, D. R., Flocke, F., Lueb, R. A., Lee-Taylor, J. M., Stroud, V., and Travnicek, W.: Distributions of brominated organic compounds in the troposphere and lower stratosphere, J. Geophys. Res., 104(D17), 21 513-21 535, 1999.

Schmidt, U., Kulessa, G., Klein, E., Röth, E.-P., Fabian, P., and Borchers, R.: Intercomparison of balloon borne cryogenic whole air samplers, Planet. Space Sci., 35, 647-656, doi:10.1016/00320633(87)90131-0, 1987.

Sinnhuber, B.-M. and Folkins, I.: Estimating the contribution of bromoform to stratospheric bromine and its relation to dehydration in the tropical tropopause layer, Atmos. Chem. Phys., 6, 4755-4761, 2006, http://www.atmos-chem-phys.net/6/4755/2006/.

Solomon, S.: Stratospheric ozone depletion: a review of concepts and history, Rev. Geophys., 37, 275-316, 1999.

Tuck, A. F., Hovde, S. J., Kelly, K. K., Reid, S. J., Richard, E. C., Atlas, E. L. Donnelly, S. G., Stroud, V. R., Cziczo, D. J., Murphy, D. M., Thomson, D. S., Elkins, J. W., Moore, F. L., Ray, E. A., Mahoney, M. J., and Friedl, R. R.: Horizontal variability 1-2 km below the tropical tropopause, J. Geophys. Res., 109, D05310, doi:10.1029/2003JD003942, 2004.

Worton, D. R., Mills, G. P., Oram, D. E., and Sturges, W. T.: Gas chromatography negative ion chemical ionization mass spectrometry: Application to the detection of alkyl nitrates and halocarbons in the atmosphere, J. Chromatogr. A., 1201, 112-119, 2008.

WMO 2007: World Meteorological Organization/United Nations Environment Programme, Scientific Assessment of Ozone Depletion: 2006, Global Ozone Research and Monitoring ProjectReport No. 50, Geneva, Switzerland, 2007. 